\title{
PENGEMBANGAN EKONOMI KREATIF INDUSTRI KECIL MENENGAH KOTA SERANG DI MASA PANDEMI COVID-19
}

\author{
Agus Santosa
}

Universitas Terbuka Tangerang Jawa Barat, Indonesia

Email: agusto@ecampus.ut.ac.id

\section{Abstract}

The purpose of this research is to explore involvement SMEs in increasing creativity and how to manage the creative economy during the Covid-19 pandemic and New Habit Adaptation (IMR) supported by survey methods. As the unit of analysis it represents a number of individuals (customers) taken randomly totaling 52 people (the facility uses the google-form application). This research method uses a custodia survey technique from a group of poluasi large and small. The results showed that the development of IKM through strengthening branding in the Creative Economy; Promotion and Marketing in digital; and mapping internal and external factors, strengthening a healthy climate, offering business capital assistance, protecting business from the government, seeking to develop partner-business strength, developing promotions, and developing equal cooperation. However, currently the creative economy in Serang City is faced with obstacles during the Covid-19 Pandemic where IKM entrepreneurs have to collapse and go bankrupt because they cannot survive due to the global depression of the Covid-19 pandemic. It needs concrete steps and concrete efforts from the local government to pay attention to the existence of IKM in Serang City as a promising source of local economic development.

Keywords: Pengembangan IKM; Covid-19; Economic Growth; Promotion; Marketing

\section{Abstrak}

Tujuan penelitian ini untuk mengeksplorasi pelibatan Industri Kecil Menengah (IKM) dalam meningkatkan kreativitas dan cara mengelola ekonomi kreatif selama masa pandemi Covid-19 dan Adaptasi Kebiasaan Baru (AKB) yang didukung metode survei. Metode penelitian ini menggunakan teknik survei kuanitatif dari kelompok sebuah poluasi yang besar maupun kecil. Sebagai unit analisis merepresentasikan beberapa individu (customer) diambil secara random berjumlah 52 orang (fasilitas menggunakan aplikasi google-form). Hasil penelitian menunjukkan bahwa pengembangan IKM dilakukan melalui penguatan branding dalam Ekonomi Kreatif, Promosi dan Pemasaran digital; dan memetakan faktorfaktor internal maupun eksternal, memperkuat iklim usaya yang sehat, menyodorkan bantuan modal usaha, proteksi usaha dari pemerintah, mengupayakan pengembangan kekuatan mitra-usaha, pengembangan promosi, dan pengembangan kerjasama yang setara. Namun demikian, saat ini ekonomi kreatif di Kota Serang dihadapkan pada kendala masa Pandemi Covid-19 di mana para pengusaha IKM harus kolaps dan bangkrut karena tidak sanggup bertahan 
karena depresi global pandemi Covid-19. Perlu langkah konkrit dan upaya nyata dari pemerintah setempat untuk memberikan perhatian akan keberaadan IKM di Kota Serang ini sebagai sumber pembangunan ekonomi lokal yang menjanjikan.

Kata kunci: Pengembangan IKM; Covid-19; Pertumbuhan Ekonomi; Promosi; Pemasaran

\section{Pendahuluan}

Di Indonesia ekonomi kreatif menjadi sangat penting, industri kreatif adalah salah satu sektor ekonomi yang belakangan sedang dikembangkan. Industri kreatif ini mengasah dan memanfaatkan keterampilan, bakat, kreativitas individu untuk membuka lapangan kerja baru (Avianto, 2017). Ada pun jenis ekonomi kreatif pada saat ini memiliki 17 sub sektor yang sangat berkontribusi menjadi penopang ekonomi nasional diantaranya bidang kuliner, rancang-bangun desain properti, desain-komunikasi-visual (KDV), produk cindermata, model-fashion, kerajinan, TV dan Radion bahkan di bidang kesenian lainnya (http://www.kompasiana.com, 2020). Sebagaimana dintandai dari data yang diperoleh dari Badan Ekonomi Kreatif bahwa sektor ekonomi kreatif berkontribusi sangat besar terhadap PDB nasional mencapai angka Rp1.105 triliun. Dan pada tahun 2017 angka ini naik sebesar Rp1.009 triliun, dan 2016 senilai Rp922 triliun. Sedangkan kontribusi sektor ekonomi kreatif terhadap PDB di Tahun 2019 tumbuh mencapai Rp100 triliun pertahun nya, sehingga, kontribusi sektor ekonomi kreatif di tahun 2020 diperkirakan mencapai angka sekitar Rp1.300 triliun. Selain menyumbang tinggi, sektor ekonomi kreatif tahun lalu dapat membantu meningkatkan angka penyerapan kerja sebanyak kurang lebih 17 juta orang dalam jangka satu tahun.

Ketika pandemi Covid-19 yang menyerang di Indonesia sangat pesat ini membuat perkembangan ekraf menurun. Karena virus tersebut pemerintah membuat peraturan dengan diberlakukannya secara luas tentang Pembatasan Sosial Berskala Besar (PSBB), masyarakat umum, (khususnya di Kota Serang) diminta bahkan dihimbau untuk tidak keluar rumah kalau tidak urgen, termasuk membatasi aktifitas yang berhungungan dengan ekonomi kreatif. Disamping itu, Pemerintah bersama seluruh sektor terkait terus berupaya untuk menstimulus ekonomi masyarakat agar tetap bertahan. Stimulus ekonomi kreatif menjadi salah satu alternatif yang diandalkan dari perekonomian Indonesia. Menurut data dari Badan Pusat Statistik (BPS) tentang perkembangan ekonomi sejak 3 Bulanan I di Tahun 2020 menunjukkan telah terjadi deselerasi ekonomi nasional sekitar 2,97\%. Hasil laporan dari situs Buku Warung juga menyebut terjadi penurunan pendapatan hingga 90\% pada Industri Kecil Menengah (IKM) selama empat bulan terakhir. Dapat dipastikan bahwa Pandemi Covid-19 berimbas terhadap berbagai sektor termasuk ekonomi kreatif.

Sebuah usaha yang memproduksi berbagai jenis produk dari IKM merupakan aktivitas ekonomi yang mengolah bahkan merubah bentuk barang dasar secara mekanik atau dengan olah-tangan sehingga menjadi produk jadi atau setengah jadi bahkan menjadi produk tidak bermutu menjadi barang yang lebih berkualitas kepada pengguna atau konsumen. Usaha untuk peningkatan pola persaingan IKM di masa Pandemi 
Covid-19 disamping beratnya rivalitas usaha sejenis membuat senrtal industri harus berani melawan terbat untuk mengembangkan usahanya, seperti menciptakan inovasi produksi dan layanan jasanya di samping peningkatan kompetensi pekerjanya serta menciptakan penetrasi pasar yang lebih baik. Usaha ini harus dilakukan sebagai syarat untuk mendongkrak nilai jual produk industri kreatifnya sehingga mampu bersaing dengan produk asing lain serta diharapkan bisa menampung pangsa tenaga kerja lebih banyak lagi (Supriyadi et al., 2017).

Persaingan usaha atau kompetisi usaha tentunya menjadi hal yang tidak bisa dihindari oleh pelaku usaha itu sendiri dengan tujuan tetap bertahan dalam menjalankan usahannya tersebut. Kriteria ini merupakan persoalan besar bagi pengusaha ekonomi khususnya bagi para pelaku IKM meskipun saat ini sudah menjadi program pemerintah. Pelaku usaha beranggapan bahwa rivalitas usaha memerlukan inovasi dasar dan strategi khusus dalam menciptakan persaingan sumber daya manusia yang berkualitas, menguasai teknologi, kecukupan modal serta memiliki lingungan kondusif. Lebih lanjut (Jauhari, 2010) mengungkapkan, berubaha keadaan lingkungan bisnis bakalan menciptakan usaha agar berjalan efisien dan mampu bersaing dengan produksi dalam negeri lainnya. Salah satu cara yang dikemas oleh industri saat ini adalah mempromosikan barang berkualitas, murah, dan terjangkau kepada konsumennya. Sehingga persaingan itu harus ada di setiap industri demi menjaga kualitas tadi, hal inipun berlaku bagi IKM di Indonesia agar tercipta kompetisi berbasis klaster (Asmara \& Rahayu, 2013). Dengan demikian, setelah terbentuknya cluster kompetisi yang bejalan berkesinambungan maka terciptalah pengetahuan baru berupa strategi pengembangan produk lokal tersebut (Tambunan, 2012). Dengan lahirnya cluster, dengan sendirinya akan menumbuhkan inovasi yang bermuara akhir pada terbentuknya daya inovasi kolektif dan rivalitas wilayah usaha (Nuryanto, 2016). Kluster-kluster IKM tersebut nantinya akan menjadi salah satu penggerak ekonomi lokal meskipun pada praktekya masih banyak kendala yang dihadapi oleh pelakuk IKM itu sendiri maupun pihak pemerintah (Ratnasari, 2013).

Tahun 2020 adalah tahun yang berat buat perekonomian dunia. Sektor ekonomi terkena dampak yang cukup signifikan. Tak pelak, pandemi corona menjadi penyebab menurunnya ekonomi di beberapa negara. Akibat adanya pandemi Corona-19 ini, sektor perekonomian babak belur. Ini menyebabkan beberapa dampak serius seperti banyaknya PHK di berbagai perusahaan, besar maupun kecil. Tingkat pengangguran pun meningkat. Hal seperti ini tak bisa dihindari. Berangkat dari hal itu dan tidak ingin terus terpuruk, di masa Pandemi Covid-19 dan Adaptasi Kebiasaan Baru (AKB), pelaku usaha ekonomi kreatif di Kota Serang mencoba untuk kembali bergeliat, sebagian orang mulai memutar otak untuk menangani masalah tersebut, Mereka yang terkena PHK mencoba dan memilih membuka usaha baru. Mereka secara tak langsung membantu pemulihan perekonomian Indonesia dengan cara membuka usaha-usaha kecil. Dengan harapan jenis ini menjadi salah satu unggulan pemerintah dalam menaikan ekonomi, karena kontribusinya terhadap PDRB sangat besar. 
Bentuk dari usaha kecil ini bermacam-macam, namun satu garis merah yang bisa diambil adalah penerapan konsep ekonomi kreatif dalam usaha-usaha kecil tersebut. Ekonomi kreatif menjadi salah satu peluang maupun solusi di tengah keadaan yang serba tak jelas ini. Konsep ekonomi kreatif ini berbeda dengan konvensional (Sulistyo, 2010). Ada sejumlah faktor pembeda, faktor yang dimaksud dapat berupa bentuk kreatif dari pemasaran, pengemasan, promosi, hingga desain produk. Artinya produk ekonomi kreatif itu dasarnya bersumber dari pengalaman, kemampuan kreatif individu untuk menciptakan sesuatu yang bernilai bahkan bersumber dari ide dan gagasan itu sendiri. Keberaan pengusaha ekonomi kreatif nyatanya masih belum stabil di masa Pandemi Covid-19 ini bahkan tidak mampu bertahan beroperasi alias bangkrut di masa resesi global ini. Resesi ini terjadi karena pemerintah memberlakukan sistem kerja dari rumah ditambah keberlakukan jaga jarak (PSBB) oleh pemerintah sehingga mau tidak mau yang kuat harus mampu berputar otak strategi pemasaran agar ekonomi keluarga tetap berlangsung. Seperti yang telah diuraikan di atas, maka ada persoalan utama yang muncul adalah bagaimana Pengembangan Ekonomi Kreatif Industri Kecil Menengah Kota Serang di Masa Pandemi Covid-19. Di mana penelitian ini pada akhirnya dapat memberikan prediksi dalam peningkatan pemasaran digital produk unggulan yang belum diteilti oleh penelitian lainnya, di mana peneliti lain masih berproses pada pemasaran non-digital atau konvensional. Sehingga hasil penelitian ini jauh lebih bermanfaat bagi pengusaha IKM serta lebih mahir dalam mempromosikan maupun mengelola pemasaran lebih baik lagi.

\section{Metode Penelitian}

Metode penelitian ini menggunakan teknik survei kuanitatif dari kelompok sebuah poluasi yang besar maupun kecil untuk mendapatkan data yang berkaitan tentang karakteristik, periaku, hubungan variabel yang diambil dari keberadaan keterwakilan populasi tadi (Murtini et al., 2017). Di mana sumber data maupun informasi utamanya didapati dari keterwakilan responden sebagai sampel (sumber data primer) pencarian data ini digunakan berupa pertanyaan anget atau kuesioner sebagai alat instrumen pengumpulan data. Sampel yang diambil dan dijadikan uni analisisnya yaitu: customer (individu) (customer) diambil secara random berjumlah 52 orang (fasilitas menggunakan google-form); kelompok IKM Pengrajin Tas ditentukan 5 pengusaha yang memiliki modal cukup besar dan 3 pengusaha yang memiliki modal sedikit (rendah); 2 perusahaan IKM bermodal besar; 2 orang di Dinas Perindustrian dan Ekonomi Kreatif Kota Serang. Guna melengkapi data primer di atas, peneliti dibantu dengan studi kepustakaan yang relevan dengan tema penelitian di atas seperti buku, jurnal, artikel elektroik, media elektronik, dan telaah dokumentasi. Kemudian setelah data terkumpul dilakukan analisis data hasil survei tadi dengan metode anlisis SWOT berbasis evaluasi program untuk diambil beberapa langkah-langkah konkrit dalam keberlanjutan usaha ekonomi kreatif di Kota Serang. 


\section{Hasil dan Pembahasan}

\section{A. Pentingnya Branding dalam Kemasan}

Pada era ekonomi kreatif ini, mengembangkan suatu usaha diperlukan penyajian atau pengemasan yang menarik agar sepenuhnya dapat menarik minat konsumen. Konsumen tertarik karena melihat kemasan produk yang bagus dan berbeda dengan yang lain. Inilah yang disebut dengan branding (Hidayat, 2011). Para pengusaha sekarang ini dituntut untuk berpikir secara kreatif untuk membuat kemasan yang menarik, bagus, dan berbeda dengan yang lain. Branding kemasan dapat mempengaruhi nilai jual suatu barang. Pengemasan dapat disebut sebagai faktor utama produk itu dilihat. Kemasan juga menggambarkan unsur dan nilai yang dibawa pada suatu produk. Karenanya, diperlukan konsep yang matang dalam branding produk (Mukhtar \& Nurif, 2015). Segala sesuatunya harus dipikirkan secara rinci untuk menarik konsumen. Hasil survey penelitian dapat dilhat dalam tabel berikut:

Tabel 1

Survey tentang Branding Product dan Kemasan

\begin{tabular}{llll}
\hline No & \multicolumn{1}{c}{ Indikator Penilaian } & Score \\
\hline 1 & Mengetahui proses re-crafting pengemasan produk; & 0.221 \\
\hline 2 & $\begin{array}{l}\text { Mengenal konsep branding dibandingkan konsep } \\
\text { konvensional; }\end{array}$ & 0.375 \\
\hline 3 & $\begin{array}{l}\text { Stimulus ekonomi kreatif menjadi salah satu alternatif } \\
\text { untuk branding; }\end{array}$ & 0.421 \\
\hline 4 & $\begin{array}{l}\text { Menguasai desain produktif dengan berbagai } \\
\text { kombinasi bentuk, tipografi maupun gradasi warna; }\end{array}$ & 0.401 \\
\hline 5 & $\begin{array}{l}\text { Menguasai teknik-teknik berkolaborasi dalam } \\
\text { menciptakan branding baru; }\end{array}$ & 0.114 \\
\hline 6 & $\begin{array}{l}\text { Adanya label atau merek ini biasanya berkaitan } \\
\text { langsung dengan filosofi nama, terminologi, simbol, } \\
\text { atau tampilan yang berasosiasi dengan produk; }\end{array}$ & 0.204 \\
\hline 7 & $\begin{array}{l}\text { Dilakukan proses mengevaluasi kualitas produk; } \\
\text { Adanya pembinaan tentang pemasaran online untuk } \\
\text { kemasan terbaru }\end{array}$ & 0.314 \\
\hline
\end{tabular}

Sumber: Hasil Survey, 2020

Membangun branding adalah tentang mengkomunikasikan dan mengekspos merk industri yang telah dihasilkan. Usaha maksimal yang dilakukan untuk menciptakan mutu terbaik bagi konsumen tersebut adalah memberikan rasa puas atas produk yang dibelinya seperti ada pengalaman tersendiri atas pembelian produknya. Maka dari itu, pentingnya pengemasan tersebut, para pengusaha berlomba-lomba mendesian produknya dengan semenarik mungkin (Dhameria et al., 2014). Sehingga produk yang dijual berbeda dengan yang lain dari segi desain, 
bentuk, tipografi maupun gradasi warna. Selain desain kemasan, label atau merk produk juga jadi hal lain yang perlu diperhatikan.

Label dan merk membuat suatu produk dilihat dan diingat oleh para konsumen. Label atau merek ini biasanya berkaitan langsung dengan filosofi nama, terminologi, simbol, atau tampilan yang berasosiasi dengan produk (Purbohastuti, 2017). Proses pemberian merk juga memberikan manfaat yang sangat nyata dalam membentuk pembeda produk. Manfaat tersebut antara lain; membantu pembeli mengidentifikasi produk, membantu proses keputusan membeli atau tidak, membantu pembeli mengevaluasi kualitas produk,mendorong pembelian berulang, memfasilitasi usaha promosi, dan membantu mencipkatan loyalitas pelanggan. Jadi bisa dikatakan bahwa untuk memulai suatu usaha diperlukan branding agar produknya lebih menarik untuk di jual sekaligus lebih dikenal khalayak luas. Branding jadi hal penting dalam era ekonomi kreatif seperti sekarang ini.

Permasalahan tersebut di atas secepatnya dibenahi dengan mengambil langkah kebijakan penguatan para pengusaha ekonomi kreatif di Kota Serang agar segera keluar dari permasalahan regional. Bentuk nyata dari kegiatan tersebut bisa mencanangkan suatu dialog dan partisipasi pengembangan IKM, sehingga IKM dapat segera menjadi bagian riil dari pasar lokal ekonomi rakyat yang memang tumpuannya berada dipijakan kakinya sendiri, terdesentralisasi, ragam-corak dan sebagai kelompok usaha mandiri yang bisa menjadi penopang saat perekonomian ditempa resesi. Berfungsinya kekuatan IKM saat ini menjadi bagian penting dan nyata dalam tata ekonomi untuk lapisan bawah. Selain sumber nafkah hajat hidup orang banyak yang menyediakan potensi untuk menciptakan lahan pekerjaan baru bagi lingkungan masyarakat itu sendiri (Deti, 2017). Sebagai pengusaha kecil, IKM senantiasa terperdaya masalah keterbasan dana, teknik-teknik produktif, lemahnya strategi pemasaran, dan pemanfaatan teknologi. Upaya untuk menaikkan kompetensi usaha kecil tersebut agar bisa bersain dalam usaha ekonomi secara luas, dibutuhkan serangkan pendampingan terpadu dan terusmenerus dilakukan khususnya menangani terbatasnya pengetahuan, informasi maupun pendanaan (Putra, 2012).

Hal lainnya sejak diberlakukannya secara nasional tentang pola perdagangan bebas, telah membuat para pengusaha ekonomi kreatif khususnya di Kota Serang, bahkan dari pusat sampai ke pelosok desa, haru membanting-stir suatu cara agar dapat bersaing dengan kehadiran pengusaha atau produsen dari luar. Para aktor usahawan tersebut, selain bisa berkompetisi dengan pengusaha lokal, mau tidak mau, siap atau tidak siap, selain harus beradu-kening dengan produk-produk yang datangnya dari luar dengan harga yang relatif lebih murah, tentunya kejadian ini berdampak serius usahwan lokal IKM di Kota Serang khususnya. 


\section{B. Promosi dan Pemasaran di Era Ekonomi Kreatif}

Selain branding, hal yang tak bisa dilepaskan dalam dunia usaha adalah promosi dan pemasaran. Di era ekonomi kreatif ini, promosi bisa dijalankan dengan bantuan teknologi digital. Perkembangan teknologi yang sangat cepat menuntut pelaku ekonomi kreatif harus memutar otak untuk melakukan pemasaran dengan cara baru. Maka dari itu pelaku ekonomi sekarang mulai selektif dalam memasarkan produknya. Karena jika dipikir, melakukan pemasaran secara konvensional mungkin sudah tidak efektif lagi. Dengan pergeseran budaya dan segala kemudahan yang ditawarkan, pelaku ekonomu dapat memasarkan produknya mengutamakan jejaring sosial dan media-media promosi virtual lainnya. Banyak kemudahan yang ditawarkan dengan promosi secara virtual. Selain lebih banyak orang yang dijangkau, promosi virtual lewat medsos atau jejaring sosial juga jadi menambah nilai dari suatu produk.

\section{Tabel-2}

Survey tentang Promosi dan Pemasaran

\begin{tabular}{lll}
\hline No & \multicolumn{1}{c}{ Indikator Penilaian } & Score \\
\hline 1 & $\begin{array}{l}\text { Frekuensi Penjualan melalui media promosi } \\
\text { marketing }\end{array}$ & 1,542 \\
\hline 2 & $\begin{array}{l}\text { Kualitas promosi konten isi, desain, posisi dan media } \\
\text { yang digunakan }\end{array}$ & 0,104 \\
\hline 3 & Ketepatan waktu untuk mencapai target & 2,201 \\
\hline 4 & Waktu promosi yang dilakukan oleh pengusaha IKM & 1,115 \\
\hline 5 & Presentasi biaya promosi yang dilakukan IKM & 0,078 \\
\hline 6 & Tingkat penjualan per-sales-person IKMM & 0,089 \\
\hline 7 & Indeks Kepuasan Konsumen penjualan IKM & 0,105 \\
\hline 8 & Rasio produktivitas volume penjualan oleh IKM & 1,109 \\
\hline & \multicolumn{2}{c}{ Total Score B } \\
\hline
\end{tabular}

Sumber: Hasil Survey, 2020

Di era ekonomi kreatif seperti sekarang ini, rasanya wajib mengunakan media sosial dalam pemasaran suatu produk. Mulai dari Instagram, Fcebook, Twitter bahkan Youtube. Pada dasarnya, menggunakan media sosial lebih mudah menjangkau pasar serta mampu meningkatkan kedekatan sosial dengan pelanggan atau konsumen yang dituju. Selain dengan pendekatan personal melalui medsos, strategi untuk meningkatkan kepuasan pelanggan atau konsumen dengan pemberian insentif juga tak kalah pentingnya (Alyas, 2017).

Berikan insentif bagi pelanggan setia seperti diskon dan bonus khusus, insentif tersebut membuat pelanggan jadi lebih setia. Pemilik usaha kecil dan menengah perlu pemasaran yang efektif dan tepat sasaran. Harus mengunakan cara atau strategi yang tepat dalam pemasaran produk yang akan dijajakan. Dengan begitu, usaha bisa lebih mudah untuk dikembangkan. Penerapan konsep ekonomi kreatif memang penting pada masa-masa sulit seperti sekarang ini. Dengan penerapan yang tepat, ekonomi kreatif jadi solusi bagi para usahawan 
kecil yang hendak membentangkan usahan produksinya secara maksimal. Berdasarkan hasil survey pemetaan tersebut, maka disusun grafik survei branding, promosi dan pemasaran berikut ini:

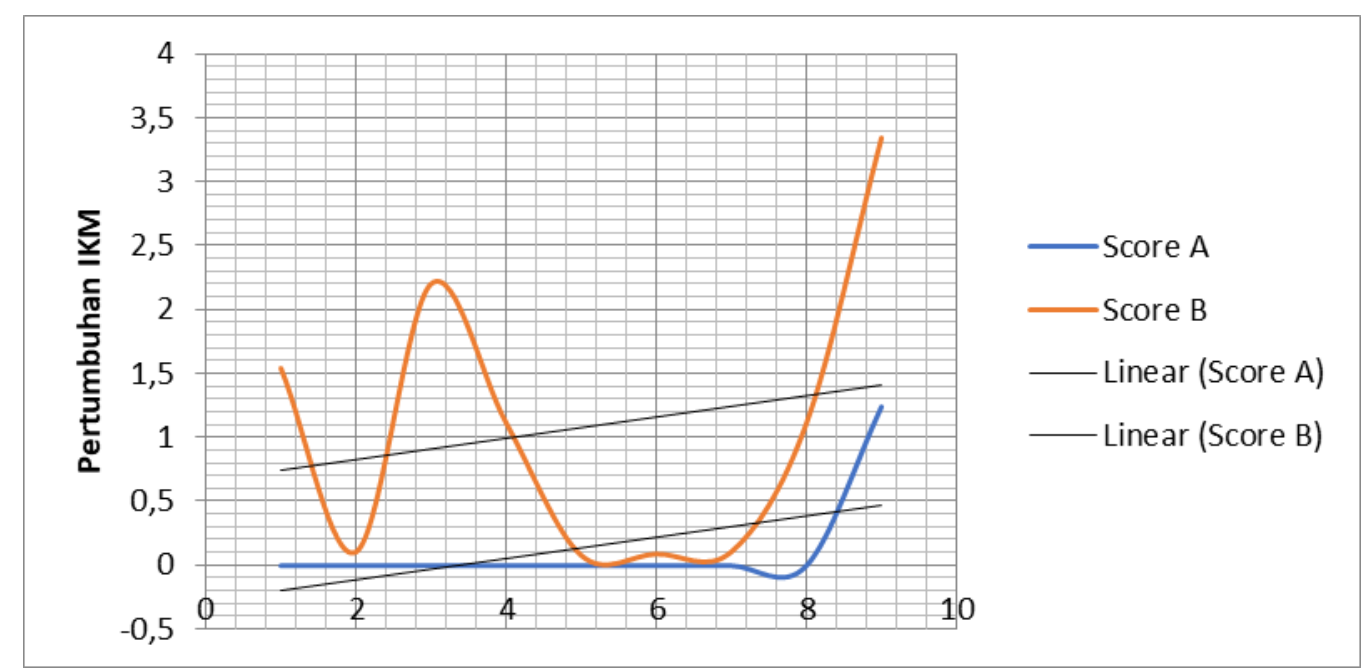

\section{Grafik 1}

\section{Pertumbuhan IKM melalui branding, promosi dan pemasaran}

(Sumber: Hasil Penelitian, 2020)

Berdasarkan gambar di atas, terlihat bahwa pertumbuhan IKM di Kota Serang dari aspek pemasaran, promosi dan branding menurun. Bila dilihat dari nilai score A (branding dan merk) turun drastis hingga di angka 1,243 sedangan score B (Promosi dan Pemsaran) cukup meningkat 3,343. Hal ini artinya pada masa Pandemi ini bisa diprediksi kebutuhan konsumen melalui kajian riset produk yang sesuai dengan kebutuhannya. Bagi pengusaha yang telah memulai bisnisnya dapat menggandeng kesesuaian kebutuhan konsumen dengan barang yang telah diproduksinya. Sedangkan promosi dan pemasaran menunjukkan peluang yang cukup signifikan dalam kondisi pandemi seperti ini, sosial media atau interaksi daring lainnya menjadi wadah paling jitu untuk mempromosikan produk andalannya dalam bentuk promosi-iklan maupun diskon untuk menarik pelanggan. Pengusaha perlu memanfaatkan platform seperti Instagram, Facebook, Twitter, ataupun lainnya untuk mempromosikan dan menjual produk.

\section{Permasalam IKM DI Kota Serang}

Adanya permasalahan umum yang sedang dihadapi oleh IKM di Kota Serang, berdasarkan hasil observasi lapangan terungkap hal-hal berikut:

1. Permasalahan aspek internal IKM; yaitu beberapa permasalahan secara intern yang masih menjadi beban untuk pertumbuh-kembangkan IKM di Kota Serang yaitu:

- Minimnya pendanaan artinya dana usaha untuk penunjang utama yang sangat dibutuhkan untuk menjalankan dan mengembangkan usaha 
kreatifnya. Akibat kekurangan dana tersebut sebagai alasan utamanya, bahwa sebagian besar IKM ini dimiliki oleh usaha perorangan bukan kelompok pemodal bahkan sifat usahanya tertutup hanya mengandalkan pada kepemilikan dana pribadi atau individu yang dari segi kuantitasnya sangat terbatas. Sedangkan untuk persyaratan pendanaan dari bank atau lembaga perkreditan lainnya sagat sulit diperoleh dikarenakan secara administratif maupun teknisnya sulit dipenuhi karena persyaratannya

- Minimnya tenaga kerja; IKM di Kota Serang separuhnya adalah jenis usaha kreatif yang tumbuh turun-temurun usaha keluarga yang mekanisme operasional dilakukan secara tradisional. Tentunya kondisi seperti ini mengakibatkan sangat terbatasnya tenaga kerja baik dari aspek pendidikan formal, rekognisi dan kemahirannya sehingga berakibat pada tata kelola usahanya yang sulit mengembang dengan maksimal.

- Inkonsistensi jejaring usaha serta rendahnya penetrasi pasar; Di mana setiap IKM yang berada di Kota Serang rata-rata milik usaha keluarga yang memiliki jaringan sangat terbatas di samping kemampuannya untuk penetrasi pasar. Hal ini disebabkan produk olahan hasil usahanya tersebut dapat dikatakan output kualitas tidak sesuai dengan permintaan pasar.

2. Permasalahan aspek eksternal

- Kondisi bisnis belum seutuhnya aman; Di mana kebijakan pemerintah setempat untuk membangkitkan industri kreatif IKM belum berpihak kepadanya bahkan prosesnya dari tahun ke tahun sebelumnya masih menjadi wacana penyempurnaan agenda kerja. Dampak tersebut pada akhirnya akan terjadi persaingan yang tidak seimbang antara pegusaha besar dan para pengusaha lokal di Kota Serang.

- Minimnya fasilitas dan infrastruktur yang mereka miliki sehingga kemajuan usahannya terhambat rendahnya informasi yang berhubungan dengan pengembangan usaha industri olahan mereka bahkan cenderung menurun drastis.

- Keterkaitan peran otonomi daerah; Sejak diberlakukannya UU Nomor 23 Tahhun 2014 di mana kewenangan pemerintah daerah untuk mengatur dan mengelola layanan kepada masyarat setempat berdampak pada pengurangan pelaku usaha IKM di Kota Serang karena maraknya pungutan-pungutan pajak baru yang dikenakan pada IKM tersebut. Apabila kondisi ini tidak segera ditertibkan maka terjadi kemunduran persaingan IKM. Di samping itu pula, semangat usaha kedaerahannya terkadang menumbuhkan situasi persaingan yang kurang sehat bagi pengusaha luar untuk mengembangkan alokasi usahanya di daerah tersebut khususnya di Kota Serang.

- Keterkaitan perdagangan bebas; Secara umum sudah nampak keberadaan MEA sejak Tahun 2014 dimana aktivitas APRC di Tahun 2020 nanti berimbas luas terhadap persaingan usaha bebas di Indonesia umumnya, 
khususnya pada pengusaha IKM di Kota Serang. Sehingga suka tidak suka peran IKM dipaksa untuk membuat usaha produksi secara efisien dan efektif serta diharapkan memperoleh produksi standar internasional sesuai tuntutan kebutuhan pasar global seperti standar ISO 9000, isu lingkungan ISO 14.000 bahkan isu lainnya seperti HAM-ketenagakerjaan. Sebenarnya isu ini tidak begitu memihak secara tepat kepada para pengusaha IKM yang justru harus tetap berkiprah dan memperjuangkan produk unggulan berkualitas global yang diakui secara nyata.

- Kadar kadaluwarsa atau klise pendek; Artinya rata-rata produk industri olahan IKM ini memiliki karakteristik produk kuliner, fashion ataupun kerajinan dengan masa kadaluwarsa yang pendek, berbeda dengan produk unggulan dari luar yang dari segi kemasan, lifetime relatif jauh tertinggal dan produknya mampu bertahan di pasar global.

- Aksesibilitas pasar global sangat terbatas hal ini menyebabkan produksinya tidak banyak karena takut tidak laku apalagi jikalau untuk bersaing di pasar global, nasional maupun internasional. Permasalahn kedua variabel tersebut kemudian dipetakan melalui Analisis SWOT dan diperoleh deskripsi sebagai berikut:

\section{Tabel 3}

Internal dan Eksternal Faktor Permasalahan IKM di Kota Serang

\begin{tabular}{clr}
\hline No & IFE - (Internal Factor Elements) & $\begin{array}{c}\text { Avg. } \\
\text { Score }\end{array}$ \\
\hline 1 & Kurangnya Permodalan & 0,62 \\
\hline 2 & Tenaga kerja lokal yang Terbatas & 0,42 \\
\hline 3 & Rendahnya jaringan usaha dan penetrasi pasar & 0,38 \\
\hline & $\begin{array}{l}\text { Produk dan branding sangat terbatas dan kualitas } \\
\text { rendah }\end{array}$ & 0,22 \\
\hline & & Total \\
\hline & $\mathbf{1 , 6 4}$ \\
\hline NO & EFE - (External Factor Elements) & Avg. \\
\hline 1 & Iklim usaha belum sepenuhnya aman & Score \\
\hline 2 & Terbatasnya pengusaha-pengusaha besar & 0,54 \\
\hline 3 & Keterkaitan otonomi Daerah & 0,68 \\
\hline 4 & Keterkaitan perdagangan bebas & 0,39 \\
\hline 5 & sifat produk dengan lifetme pendek & 0,23 \\
\hline 6 & terbatasnya akses pasar (market base) & 0,19 \\
\hline & & 0,33 \\
\hline
\end{tabular}

Sumber: Hasil Penelitian, 2020 


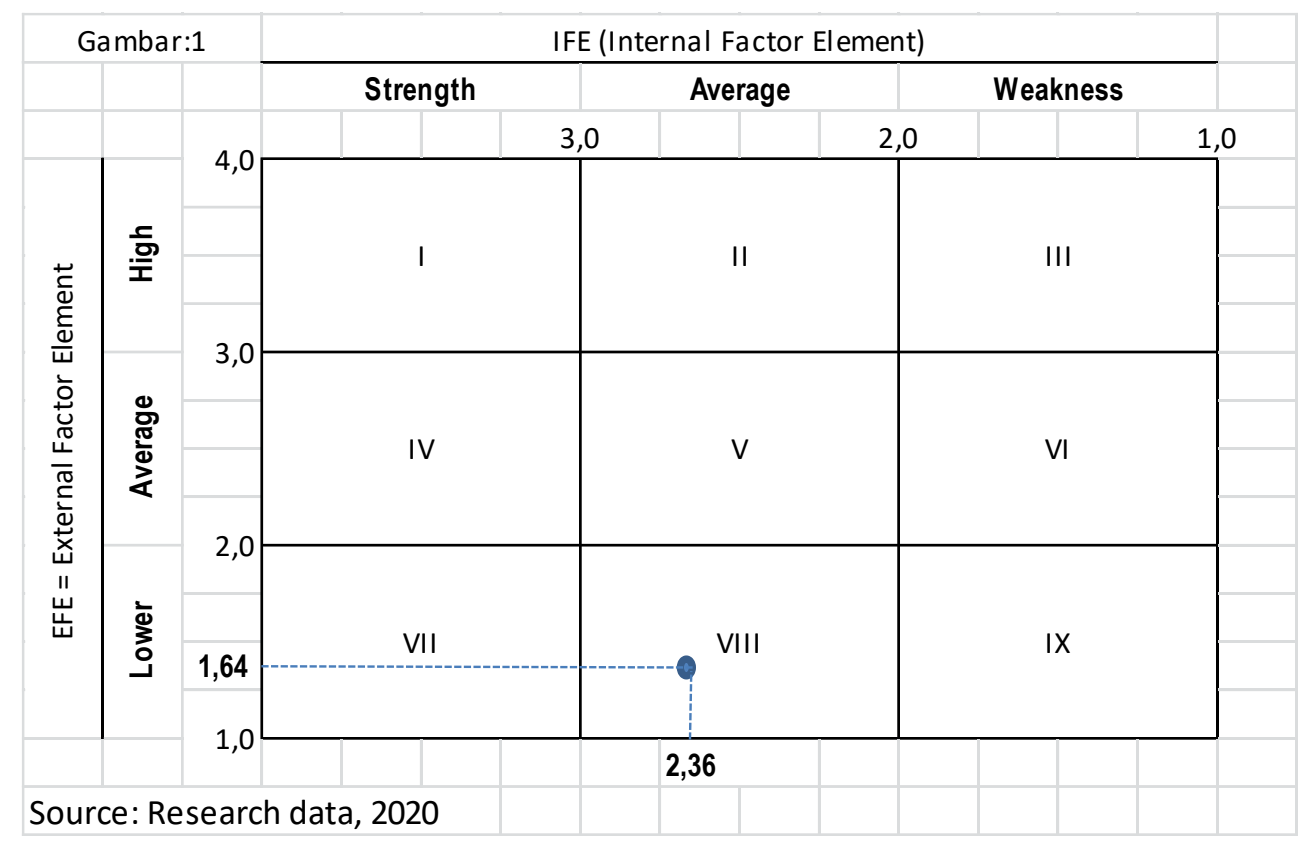

Gambar 1

Kurtosis Swot Analisis IFE dan EFE (Branding, Promosi dan Pemasaran)

Hasil analisis data kurtosis mengindikasikan beberapa permasalahan yang melanda IKM cukup besar dan penanganan secepatnya baik pengelolaan aspek kinerja, aspek manajemen, pemasaran dan kinerja organisasinya. Temuan di lapangan menunjukkan rata-rata IKM pengeolaannya masih memprihatinkan, namun demikian, umumnya produktivitas usaha mereka menunjukkan angka yang cukup lumayan karena masih ada sebagian pengusaha IKM yang sukses menangani masalah pemasaran maupun pengelolaan kegiatan produksi usahanya. Melihat deskripsi seperti itu, nampaknya disinilah mulai turun tangan peran pemerintah setempat untuk turut serta memperhatikan sekaligus mengembangkan IKM melalui pembinaan berkelanjutan seperti branding, promosi, pemasaran dan pendampingan. Dari hasil kurva kurtosis di atas maka menunukkan peranan branding, promosi dan pemasaran tadi dibawah rata-rata cukup dan berada pada Kuadran VIII (1,64 - 2,36). Artinya hampir semua pengusaha IKM di Kota Serang belum mengandalkan elektronik atau digital pemasaran, ketiga halnya hanya mengandalkan insting dalam memulai maupun menjalankan usahanya. Sehingga jarang sekali diawali suatu kajian khusus mengenai lokasi stratgei, forecasting maupun penetrasi pasar. Kondisi ini akhirnya bermuara pada kesulitan upaya pengembangan usahanya meskipun usaha ini merupakan andalan pemerintah sebagai solusi pengurangan angka kemiskinan maupun pengangguran.

Beberapa usaha pengembangan ekonomi lokal IKM di Kota Serang ini, pada prinsipnya salah satu proses aktualisasi keinginan pembangunan ekonoi daerah yang berlandaskan nilai demokrasi berkeadilan dan universal, di mana peran pembangunan ekonomi daerah itu melibatkan seluruh komponen masyarakat, tokoh agama, budaya, sampai pada tokoh desa. Beragam potensi yang 
hadir selama ini telah menjadi usaha rakyat di Kota Serang tetap harus digiatkan sedemikian rupa agar lebih maju dan berkembang seperti kota lainnya yang menjadi pesaing wilayah ini. Di mana pembangunan ekonomi daerah seyogyanya tidak harus berpijak di perkotaan saja, akan tetapi sebaiknya merata di seluruh pedesaan di Kota Serang itu sendiri.

Berdasarkan konsep pengembangan di atas, maka peran IKM bisa dengan segera berkembang sebaiknya dilakukan dua hal berikut, pertama dilakukannya perluasan basis para aktor ekonomi dalam proses produksinya; kedua adalah penerapan label customer satisfaction. Sehingga bila diterapkannya pola ini diharapkan kedepannya baik produsen maunpun konsumen sama-sama diberdayakan dengan berimbang. Namun kenyataannya berkata lain, sektor IKM justru sangat sulit bergandengan tangan dengan stakeholde dikarenakan lingkungan usaha yang dihadapinya terkadang membuat penusaha enggan untuk menjalin kolaboratif sehingga hanya mengandalkan pemerintah daerah. Sejalan dengan corak usaha produksinya tersebut serta kesesuaian dengan fenomena masalah yang dihadapi IKM tentunya berbeda pula mulai dari masalah lokasi, produktivitasnya, maupun permodalan. Dan inilah realitas yang menjadi penyebab sulitnya dibuat suatu pattern-policy bagi program-program pemberdayaan IKM di Kota Serang yang dapat di desain secara desentralisasi dimulai dari tingkat pusat sampai ke tatanan teknis daerahnya. Sebagai usaha untuk mengembangan dan menumbuhkembangkan IKM harus dimulai dari masalah internal yang ada di Kota Serang ini secara bertahap dicarikan alternatif startegis kebijakan yang tentunya memudahkan dan menguntungkan pengusaha itu sendiri yang kerap selama ini hanya terperangkap dalam bayangan program pemberdayaan yang tidak jelas peruntukannya.

Ditinjau dari presfektif permasalahan IKM di Kota Serang tersebut, sebagai tindaklanjut pengembangan IKM pada prinsipnya merupakan tanggung jawab bersama masyarakat dengan pemerintah. Maka langkah konkrit yang perlu diambil sebagai prioritas kebijakan IKM di Kota Serang meliputi:

a. Memperkuat Iklim Usaha yang kondusif; Peran Pemerintah Kota Serang mengeluarkan regulasi yang memudahkan para IKM untuk berpartisipasi dalam pembangunan ekonomi lokal seperti mempermudah perizinan usaha dan keringanan pajak.

b. Program Permodalan; Jika diperlukan, pemerintah Kota Serang seyogyanya bisa menambah skema kredit usaha rakyat dengan persyaratan yang mudah bagi pengusaha IKM serta membantu bantuan teknis lainnya seperti jasa formal, skema penjaminan, kemitraan dan modal ventura.

c. Proteksi usaha IKM; Pemberian program-program perlindungan industri kreatif dengan meminimalisir kerugian usaha dengan tetap bermuara pada aturan atau regulasi yang merakyat.

d. Memperkuat Program Kemitraan; Program ini perlu dikembangkan baik di lingkungan Kota Serang itu sendiri ataupun di luar wilayah. Hal ini 
dimaksudkan agar terjadi simbosis-mutualisme yang salaing menguntungan kedua belah pihak, tentunya setelah diperkuatnya beberapa peraturan dasar yang menjalin bentuk kerjasama keduanya itu, dan tiada lain untuk menghindari adanya monopoli. Selanjutnya untuk menumbuhkembangkan IKM di Kota Serang perlu pula dibangun konsep trasnformasi ekonomi lokal ke arah transformasi ekonomi baru.

Secara detail, langkah konkrit pengembangan IKM di Kota Serang dilaksanakan melalui pendekatan-pendekatan terpadu pemerintah dengan merefleksikan RPJMD tahun anggaran berjalan, selain itu melakukan pendampingan dan sosialisasi secara berkelanjutan terutama program-program yang berkaitan dengan pengembangan ekonomi daerah jangka panjang. IKM Kota serang rata-rata didominasi pengusaha level menengah ke bawah, secara perlahanlahan menyempurnakan pola industrialisasi terpadu dan sistem korporasi, langkah ini dinilai sangat tepat mengingat para IKM Kota Serang sebenarnya sudah mulai menggeliat mengembangkan usahanya baik melalui media digital maupun penetrasi pasar, minimal ada bentuk kemauan yang utuh dari para pengusahanya itu sendiri. Semua itu dapat terlaksana dengan baik apabila kedua belah pihak, pemerintah, stakeholder, swasta dilandasi semangat idealisme ekonomi kerakyatan dan inisiasi kebersamaan membangun daerah untuk lebih maju. Hasil penelitian ini, bila memungkinkan ke depannya bisa mengusung konsep pembangunan ekonomi lokal IKM berbasis pasar desa, sehingga merambah petapeta pemasaran terpadu yang dapat memperpanjang usia produksi dan tetep menambah keuntungan ekonomi bagi keluarga dan kesejahteraan masyarakat di lingkungan industri wilayah Kota Serang.

\section{Kesimpulan}

Pengembangan Industrti Kecil dan Menengah (IKM) di era global dampak Pandemi Covid-19 ini, peran pemerintah sudah membuat langkah konkrit agar sektor yang dekat dengan kemampuan daya beli ekonomi rendah ini dapat terus menjalankan usahanya dengan baik, di satu sisi keuntungan pemerintah tetap memberikan kontribusi signifikan bagi pembangunan ekonomi daerah. Hal ini cukup beralasan bahwa pengembangan IKM berbasis ekonomi lokal, seyogyanya sudah menjadi tugas bersama pemerintah pusat dan daerah demi mensukseskan keadilan sosial bagi seluruh rakyat Indonesia. Khusus IKM di Kota Serang dimana pada masa Pandemi Covid-19 ini omsetnya menurun drastis baik dari pengembangan branding merk, promosi maupun pemasaran. Pelaku IKM di Kota Serang yang saat ini sudah mencoba tetap eksis di tengah ketidakpastian kebijakan saat ini, diantaranya telah berani beradaptasi usahanya, salah satunya adalah memilah-milah pembelian bahan baku yang tidak begitu penting dan memanfaatkan sumber bahan yang murah. Para pengusaha IKM Kota serang ratarata didominasi pengusaha level menengah ke bawah, secara perlahan-lahan menyempurnakan pola industrialisasi terpadu dan sistem korporasi, langkah ini dinilai sangat tepat mengingat usaha produksi sudah mulai menggeliat untuk dikembangkan 
Agus Santosa

baik melalui media digital maupun penetrasi pasar, minimal ada bentuk tekad yang bulat dari para pengusahanya itu sendiri. Semua itu dapat terlaksana dengan baik apabila kedua belah pihak, pemerintah, stakeholder, swasta dilandasi semangat idealisme ekonomi kerakyatan dan inisiasi kebersamaan membangun daerah untuk lebih maju. 


\section{BIBLIOGRAFI}

Alyas, M. R. (2017). Strategi Pengembangan Usaha Mikro, Kecil dan Menengah Dalam Penguatan Ekonomi Kerakyatan (Studi Kasus Pada Usaha Roti Maros di Kabupaten Maros). Sosiohumaniora.

Asmara, A. Y., \& Rahayu, S. (2013). Meningkatkan daya saing industri kecil menengah melalui inovasi dan pemanfaatan jaringan sosial: pembelajaran dari klaster industri software di India. Sustainable Competitive Advantage (SCA), 3(1).

Avianto, B. N. (2017). Analisis Pengembangan Home Industri Unggulan Kaos Etnik Khas Cirebon di Kecamatan Plered Kabupaten Cirebon. Syntax Literate; Jurnal Ilmiah Indonesia, 2(5), 48-57.

Deti, S. (2017). Pemberdayaan Ekonomi Umat Melalui Pembiayaan Mikro Syariah. Jurnal El Jizya (Jurnal Ekonomi Islam) Vol, 5.

Dhameria, V., Ferdinand, A. T., \& Mudiantono, M. (2014). Analisis Pengaruh Keunikan Desain Kemasan Produk, Kondusivitas Store Environment, Kualitas Display Produk Terhadap Keputusan Pembelian Impulsif (Studi Pada Pasaraya Sri Ratu Pemuda Semarang). Diponegoro University.

Hidayat, M. J. (2011). Tinjauan Kognisi Desain Produk Kemasan Sebagai Unsur Identitas Budaya Populer Atas Produk Kemasan Makanan Industri Kecil Menengah (IKM). Jurnal Kawistara, 1(3).

Jauhari, J. (2010). Upaya pengembangan usaha kecil dan menengah (UKM) dengan memanfaatkan e-commerce. Jurnal Sistem Informasi, 2(1), 1-12.

Mukhtar, S., \& Nurif, M. (2015). Peranan packaging dalam meningkatkan hasil produksi terhadap konsumen. Jurnal Sosial Humaniora (JSH), 8(2), 181-191.

Murtini, J. T., Januar, H. I., \& Sugiyono, S. (2017). Upaya Pengurangan Cemaran Logam Berat Pada Daging Kerang Hijau (Perna Viridis) Dengan Larutan Kitosan. Jurnal Penelitian Perikanan Indonesia, 10(3), 7-10.

Nuryanto, N. (2016). Optimalisasi Kinerja Ekspor Umkm Furniture Di Jawa Tengah Melalui Aplikasi Indonesia National Single Window (Insw). Sens2.

Purbohastuti, A. W. (2017). Faktor-Faktor Yang Mempengaruhi Keputusan Pembelian Handphone Samsung Pada Mahasiswa D3 Marketing. Tirtayasa Ekonomika, 12(1), $53-75$.

Putra, R. E. (2012). Pengaruh Nilai Investasi, Nilai Upah, dan Nilai Produksi Terhadap Penyerapan Tenaga Kerja Pada Industri Mebel di Kecamatan Pedurungan Kota Semarang. Economics Development Analysis Journal, 1(2).

Ratnasari, A. (2013). Peranan Industri Kecil Menengah (IKM) dalam Penyerapan 
Agus Santosa

Tenaga Kerja di Kabupaten Ponorogo. Jurnal Pendidikan Ekonomi (JUPE), 1(3).

Sulistyo, S. (2010). Pengembangan USAha Kecil dan Menengah dengan Basis Ekonomi Kerakyatan di Kabupaten Malang. Jurnal Ekonomi Modernisasi, 6(1), 58-73.

Supriyadi, E., Merawaty, E. E., Derriawan, D., \& Salim, F. (2017). Analisis FaktorFaktor Dalam Meningkatkan Daya Saing Industri Kecil Menengah Di Tangerang Selatan (Studi Kasus: Ikm Sepatu). Jurnal Kawistara, 7(2), 134-143.

Tambunan, T. T. H. (2012). Peran usaha mikro dan kecil dalam pengentasan kemiskinan di daerah. Jurnal Bina Praja: Journal of Home Affairs Governance, 4(2), 73-92. 